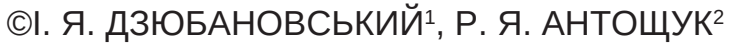

ДВН3 “Тернопільський державний медичний університет імені І. Я. Горбачевського МОЗ України” Волинський обласний госпіталь ветеранів війни²

\section{Бактеріальний “пейзаж” гнійного осередку та принципи антибактеріальної терапії у хворих із синдромом діабетичної стопи}

\begin{abstract}
Мета роботи: оцінка бактеріального спектра та ефективності призначення антибактеріальної терапії у хворих $з$ синдромом діабетичної стопи.

Матеріали і методи. Проаналізовано результати лікування 269 хворих (148 (55,01\%) чоловіків і 121 (44,09\%) жінок), які перебували на стаціонарному лікуванні в хірургічному відділенні з остеомієлітним центром на базі Волинського обласного госпіталю ветеранів війни з приводу гнійно-некротичних ускладнень СДС. Всі обстежені пацієнти попередньо проходили лікування в хірургічних стаціонарах області з приводу гнійно-некротичних процесів СДС, яким проводили емпіричну антибіотикотерапію тривалістю до 10 днів. Нейропатичну форму СДС встановлено у 84 (31,2 \%) пацієнтів, змішану - 148 (55,01 \%), ішемічну - 37 (13,7 \%). Поширеність гнійно-некротичного процесу у хворих з СДС, відповідно до класифікації Wagner: I ступінь - 20 (7,4 \%), II ступінь - 92 (34,2 \%), III ступінь - 70 (26 \%), IV ступінь - 65 (24,2 \%), V ступінь - 22 (8,2 \%). Комплекс бактеріологічних досліджень полягав у дослідженні ранового ексудату з ідентифікацією мікрофлори гнійнонекротичного вогнища й оцінкою їі чутливості до антибіотиків та цитологічному дослідженні мазків-відбитків 3 ранової поверхні. Ідентифікацію збудників інфекційного процесу здійснювали методом посівів на відповідні живильні середовища, а чутливість до антибіотиків визначали диско-дифузійним методом.

Результати досліджень та їх обговорення. Мікробний пейзаж гнійно-некротичних вогнищ у хворих із ЦД мав переважно полівалентний характер у 54,6 \% випадків, а монокультуру у 45,4\% пацієнтів. Найбільшу кількість мікробних асоціацій, що висівалися з первинного гнійного осередку, склали аеробні асоціації - 54,6 \%. Аеробно-анаеробні асоціації висівалися в поодиноких випадках, а висівання анаеробних асоціацій не спостерігали. Основним представником змішаної аеробної інфекції був Staphylococcus aureus. Найчастіше Staphylococcus aureus висівався разом з грампозитивними паличками - Еnterococcus faecalis, Corynebacterium xerosis та Staphilococcus epidermidis. Найбільше клінічне значення з групи неферментуючих мікроорганізмів у складі аеробних асоціацій має Pseudomonas aeruginosa. Результати дослідження чутливості мікроорганізмів при госпіталізації свідчать про високу стійкість мікрофлори до антибіотиків I-II поколінь групи пеніцилінів, цефалоспоринів. Антибіотиками резерву залишаються препарати групи карбапенемів, оксазолідінонів, глікопептидів.
\end{abstract}

Ключові слова: синдром діабетичної стопи; бактеріальний пейзаж; антибіотикочутливість.

Постановка проблеми і аналіз останніх досліджень та публікацій. Синдром діабетичної стопи (СДС) визначається як патологічний стан стоп хворого із цукровим діабетом (ЦД), що виникає на тлі ураження периферичних нервів, судин, шкіри й м'яких тканин, кісток і суглобів, і проявляється гострими й хронічними виразками, кістковосуглобовими ураженнями і гнійно-некротичними процесами. Таким чином, СДС - це, насамперед, гнійно-деструктивні ураження нижніх кінцівок внаслідок ЦД. Близько 85 \% цих уражень становлять трофічні виразки стоп, а частину, що залишилася - абсцес, флегмона, остеомієліт, тендовагініт, гнійний артрит й інші процеси, що розвиваються або як ускладнення трофічної виразки, або первинно, без попередньої виразки. У цілому виразкові ураження стоп розвиваються в $4-20 \%$ хворих із ЦД протягом життя й спостерігаються в $6-20 \%$ госпіталізованих хворих. Найбільше частоте виразок стоп спостерігали у віці 45 - 64 років.

Виникнення гнійно-некротичної рани стопи у хворих на ЦД погіршує перебіг діабету, формуючи замкнене коло, розірвати яке можна тільки після ліквідації гнійного вогнища [4]. Мікро- біологічний аспект цієї проблеми пов'язаний 3 3'ясуванням ролі мікроорганізмів у виникненні, перебігу та розрішенні гнійних ускладнень. Вважають, що мікроби - основна причина гнійних ускладнень рани [5]. Їх так і називають - збудники гнійно-запальних захворювань.

На даний час основними збудниками гнійної хірургічної інфекції вважают стафілококи та грамнегатавні бактерії, котрі належать до групи Enterobacteriaceae та бактерій, які не ферментуют- роду Pseudomonas, Acinetobacter, Alcaligens [9]. Суттєва роль в етіології ранової інфекції належить облігатним неспороутворюючим анаеробним бактеріям [6, 7].

Мікробний “пейзаж” гнійних вогнищ не тільки різноманітний, але й варіабельний [3]. У міру розвитку місцевої гнійної інфекції склад мікрофлори часто змінюється, особливо у випадках неефективності лікування. Досить часто до флори гнійних вогнищ приєднуються госпітальні штами, серед яких стафілокок та синьогнійна паличка є домінуючими культурами. Характерною рисою внутрішньо-лікарняних мікроорганізмів $є$ їх висока вірулентність і стійкість до антибактеріальних препаратів, у зв'язку $з$ 
чим запальні процеси, викликані цими мікробами, характеризуються тяжким перебігом і не завжди сприятливим прогнозом [1, 2, 8, 10].

Особливістю хірургічної інфекції в сучасних умовах є подальше продовження біологічної перебудови мікрофлори в бік селекції антибіотикорезистентних штамів під впливом антибіотиків, що різко знижує ефективність консервативних методів лікування хворих із гнійними рановими процесами.

Мета роботи: оцінка бактеріального спектра та ефективності призначення антибактеріальної терапії у хворих з синдромом діабетичної стопи.

Матеріали та методи. Проаналізовано результати лікування 269 хворих (148 (55,01\%) чоловіків і 121 (44,09 \%) жінок віком від 32 до 78 років), які перебували на стаціонарному лікуванні у хірургічному відділенні з остеомієлітним центром на базі Волинського обласного госпіталю ветеранів війни 3 приводу гнійно-некротичних ускладнень СДС. Всі обстежені пацієнти попередньо лікувалися у хірургічних стаціонарах області з приводу гнійно-некротичних процесів СДС. Серденя тривалість стаціонарного лікування на попередньому етапі склала $(21,4 \pm 2,3)$ дні. Всім пацієнтам, також на ранньому етапі лікування, здійснювалася емпірична антибіотикотерапія тривалістю 10 днів. Найчастіше використовувалися антибіотики цефалоспоринового ряду. Більшість хворих (73,3 \%) була працездатно- го віку. У всіх пацієнтів діагностований ЦД з них: I типу - 18 (6,6 \%) хворих, II типу - 251 (93,4 \%), в стадії компенсації виявлено у (9,0 \%) осіб, субкомпенсації (62,40%), декомпенсації (28,60%). Відповідно до етіологічного чинника, нейропатична форма СДС була у 84 (31,2 \%) пацієнтів, змішана у 148 (55,01 \%), ішемічна у 37 (13,7\%).

Поширеність гнійно-некротичного процесу у хворих з СДС, відповідно до класифікації Wagner F.M.,1979: I ступінь - 20 (7,4 \%), II ступінь - 92 (34,2 \%), III ступінь - 70 (26 \%), IV ступінь - 65 (24,2 \%), V ступінь - 22 (8,2 \%).

Комплекс бактеріологічних досліджень полягав у дослідженні ранового ексудату з ідентифікацією мікрофлори гнійно-некротичного вогнища й оцінкою її чутливості до антибіотиків та цитологічному дослідженні мазків-відбитків із ранової поверхні. Ідентифікацію збудників інфекційного процесу здійснювали методом посівів на відповідні живильні середовища. Чутливість мікроорганізмів до антибіотиків визначали диско-дифузійним методом, кількісне дослідження мікроорганізмів розраховуючи на один грам біоптату рани.

Результати досліджень та їх обговорення. Мікробний пейзаж гнійно-некротичних вогнищ у хворих із ЦД має переважно полівалентний характер. Монокультуру виділено в 45,4\% пацієнтів, полівалентну -у 54,6 \% випадків (табл. 1).

Таблиця 1. Мікробний пейзаж гнійно-некротичних вогнищ у хворих із цукровим діабетом

\begin{tabular}{|c|c|c|c|c|c|}
\hline \multicolumn{2}{|c|}{ Мікробні асоціації } & \multirow{2}{*}{$\begin{array}{c}\text { Невропатична } \\
\text { форма n=84 } \\
8(3 \%)\end{array}$} & \multirow{2}{*}{$\begin{array}{c}\begin{array}{c}\text { Ішемічна } \\
\text { форма n=37 }\end{array} \\
5(1,9 \%)\end{array}$} & \multirow{2}{*}{$\begin{array}{c}\begin{array}{c}\text { Змішана } \\
\text { форма } n=148\end{array} \\
15(5,6 \%)\end{array}$} & \multirow{2}{*}{$\begin{array}{c}\text { Разом } \\
28(10,5 \%)\end{array}$} \\
\hline Монокультура & St. aureus & & & & \\
\hline & St. epidermidis & $5(1,9 \%)$ & $2(0,7 \%)$ & $11(4 \%)$ & $18(6,6 \%)$ \\
\hline & Enterococcus faecalis & $4(1,5 \%)$ & $2(0,7 \%)$ & $14(5,2 \%)$ & $20(7,4 \%)$ \\
\hline & Proteus & $5(1,9 \%)$ & $1(0,4 \%)$ & $7(2,7 \%)$ & $13(5,0 \%)$ \\
\hline & Enterobacter & $5(1,9 \%)$ & $3(1,1 \%)$ & $11(4 \%)$ & $19(7 \%)$ \\
\hline & Corynebacterium spp. & 0 & 0 & $2(0,7 \%)$ & $2(0,7 \%)$ \\
\hline & Citrobacter & $2(0,7 \%)$ & $1(0,4 \%)$ & $3(1,1 \%)$ & $6(2,2 \%)$ \\
\hline & Ps. aerugenosa & 0 & $1(0,4 \%)$ & $3(1,1 \%)$ & $4(1,5 \%)$ \\
\hline & Acinetobacter & $1(0,4 \%)$ & 0 & $2(0,7 \%)$ & $3(1,1 \%)$ \\
\hline & Candida & $4(1,5 \%)$ & 0 & $5(1,9 \%)$ & $9(3,4 \%)$ \\
\hline \multirow[t]{6}{*}{$\begin{array}{l}\text { Полівалентна } \\
\text { Інші }\end{array}$} & $\begin{array}{l}\text { St. Aureus+ } \\
\text { Enterococcus faecalis }\end{array}$ & $9(3,3 \%)$ & $2(0,7 \%)$ & $11(4 \%)$ & $22(8 \%)$ \\
\hline & $\begin{array}{l}\text { St.aureus } \\
\text { +Corynebacterium spp. }\end{array}$ & $2(0,7 \%)$ & 0 & $2(0,7 \%)$ & $4(1,4 \%)$ \\
\hline & $\begin{array}{l}\text { St.aureus+St. } \\
\text { epidermidis }\end{array}$ & $3(1,1 \%)$ & $3(1,1 \%)$ & $12(4,5 \%)$ & $18(6,7 \%)$ \\
\hline & $\begin{array}{l}\text { St.aureus +Pseudomonas } \\
\text { aeruginosa }\end{array}$ & $24(9,0 \%)$ & $10(3,7 \%)$ & $26(9,8 \%)$ & $60(22,5 \%)$ \\
\hline & St.aureus+Acinetobacter & $9(3,3 \%)$ & $5(1,9 \%)$ & $17(6,3 \%)$ & $31(11,5 \%)$ \\
\hline & Інші & $3(1,1 \%)$ & $2(0,7 \%)$ & $7(2,7 \%)$ & $12(4,5 \%)$ \\
\hline
\end{tabular}


Найбільшу кількість мікробних асоціацій, що висівалися з первинного гнійного осередку хворих на ускладнений СДС, склали аеробні асоціації - 54,6 \%. Аеробно-анаеробні асоціації висівалися в поодиноких випадках, а висівання анаеробних асоціацій не спостерігалося. Основним представником змішаної аеробної інфекції був Staphylococcus aureus. Найчастіше Staphylococcus aureus висівався разом із грампозитивними паличками - Enterococcus faecalis, Corynebacterium xerosis та Staphilococcus epidermidis. Найбільше клінічне значення з групи неферментуючих мікроорганізмів у складі аеробних асоціацій має Pseudomonas aeruginosa. Висівання синьогнійної палички у складі мікробних асоціацій становило 22,5\%. Серед неферментуючих мікроорганізмів у складі мікробних асоціацій відмічено наявність Acinetobacter spp. - 11,5 \%.

У типових випадках збудниками поверхневих інфекцій були грампозитивні коки. В останні роки спостерігається різке зростання поширення резистентних штамів мікроорганізмів. Наявність множинних асоціацій у гнійно-некротичному вогнищі поєднується з високим мікробним обсіменінням тканин рани $10^{6}-10^{11}$ мікроорганізмів на один грам тканини. Гнійна інфекція у хворих зі ЦД перебігає тяжко, нерідко набуває септичний характер. Тяжкість процесу зумовлена швидким розвитком гнійного ураження із захопленням великих навколишніх тканин. У ранах переважають некротичні процеси, тоді як класичні симптоми запалення часом бувають слабовиражені, а деякі з них можуть бути зовсім відсутні.

Серед ідентифікованої мікробної флори переважали грампозитивні бактерії - 59,0 \%. Штами St. aureus виділені з ранового ексудату в 98 хворих (36,4 \%). Грамнегативні ентеробактерії діагностовані в 42 хворих обох груп (15,7%). При тяжких і поширених формах інфекції у хворих із СДС визначалися грамнегативні бактерії: Ps.aeruginosa 12,6\% й Acinetobacter spp. - 7,0 \%, а так само гриби роду Candida $-3,4 \%$.

Для визначення найбільш ефективних засобів лікування хворих з цукровим діабетом і наявністю гнійних ран у пацієнтів визначали чутливість виділених культур до різних антибіотиків. У таблиці 2 представлено отримані в результаті дослідження дані про чутливість мікрофлори до антибіотиків.

Антибактеріальна терапія є одним з найважливіших компонентів консервативного лікування.

Таблиця 2. Чутливість основних культур мікроорганізмів, що висіваються із ран у хворих на ускладнений синдром стопи діабетика до антимікробних препаратів

\begin{tabular}{|c|c|c|c|c|c|c|}
\hline $\begin{array}{c}\text { Найменування } \\
\text { антибактеріального } \\
\text { засобу }\end{array}$ & $\begin{array}{c}\text { St. aureus } \\
\text { n=98 }\end{array}$ & $\begin{array}{c}\text { St. epidermidis } \\
n=27\end{array}$ & $\begin{array}{c}\text { Enterococcus } \\
\text { faecalis } \\
n=31\end{array}$ & $\begin{array}{c}\text { Enterobacter } \\
n=19\end{array}$ & $\begin{array}{c}\text { Ps. aerugenosa } \\
n=34\end{array}$ & $\begin{array}{c}\text { Proteus } \\
n=13\end{array}$ \\
\hline Оксацилін & $81(82,6 \%)$ & 0 & 0 & 0 & 0 & 0 \\
\hline Гентаміцин & $59(60,2 \%)$ & $8(29,6 \%)$ & $22(70,9 \%)$ & $14(73,7 \%)$ & $23(67,6 \%)$ & $10(76,9 \%)$ \\
\hline Цефотаксим & $71(72,4 \%)$ & 17 (62,9\%) & 0 & $9(47,4 \%)$ & 0 & $9(69,2 \%)$ \\
\hline Цефтазидим & 0 & 0 & 0 & $12(63,1 \%)$ & $26(76,5 \%)$ & $11(84,6 \%)$ \\
\hline Цефтріаксон & $73(74,5 \%)$ & $21(77,7 \%)$ & $6(19,3 \%)$ & $1(5,3 \%)$ & 0 & $12(92,3 \%)$ \\
\hline Цефоперазон & $74(75,5 \%)$ & $11(40,7 \%)$ & 0 & $12(63,1 \%)$ & $27(79,4 \%)$ & $11(84,6 \%)$ \\
\hline Цефуроксим & $63(64,3 \%)$ & $21(77,7 \%)$ & $1(3,2 \%)$ & 0 & 0 & $6(46,1 \%)$ \\
\hline Цефепім & $84(85,7 \%)$ & 17 (62,9\%) & $1(3,2 \%)$ & $14(73,7 \%)$ & $29(85,3 \%)$ & $12(92,3 \%)$ \\
\hline Ванкоміцин & $98(100 \%)$ & $24(88,8 \%)$ & $27(87,0 \%)$ & 0 & 0 & 0 \\
\hline Амікацин & $91(92,8 \%)$ & $4(14,8 \%)$ & 0 & $17(89,5 \%)$ & $26(76,5 \%)$ & $12(92,3 \%)$ \\
\hline Ципрофлоксацин & $59(60,2 \%)$ & $6(22,2 \%)$ & $8(25,8 \%)$ & $18(94,7 \%)$ & $27(79,4 \%)$ & $12(92,3 \%)$ \\
\hline Меропенем & $94(95,9 \%)$ & $21(77,7 \%)$ & 0 & $19(100 \%)$ & $30(88,2 \%)$ & $12(92,3 \%)$ \\
\hline Левофлоксацин & $78(79,6 \%)$ & $22(81,5 \%)$ & $26(84 \%)$ & $17(89,5 \%)$ & $21(61,8 \%)$ & $12(92,3 \%)$ \\
\hline Лінезолід & $98(100 \%)$ & $19(70,4 \%)$ & $31(100 \%)$ & 0 & 0 & 0 \\
\hline Іміпенем & 96 (97,9\%) & 21 (77,7\%) & 21 (67,7\%) & 18 (94,7\%) & 33 (97\%) & $13(100 \%)$ \\
\hline Амоксицилін & 0 & 0 & $28(90,3 \%)$ & 0 & 0 & 0 \\
\hline Офлоксацин & $46(46,9 \%)$ & $3(11,1 \%)$ & $7(22,6 \%)$ & $16(84,2 \%)$ & $15(44,1 \%)$ & $11(84,6 \%)$ \\
\hline Ампіцилін & $5(5,1 \%)$ & 0 & $29(93,5 \%)$ & 0 & 0 & $3(23 \%)$ \\
\hline Піперацилін & $7(7,1 \%)$ & $2(7,4 \%)$ & $26(83,9 \%)$ & $6(31,6 \%)$ & $19(55,9 \%)$ & $5(38,5 \%)$ \\
\hline Метронідазол & 0 & 0 & 0 & 0 & 0 & 0 \\
\hline Лінкоміцин & $61(62,2 \%)$ & $3(11,1 \%)$ & 0 & $1(5,3 \%)$ & 0 & 0 \\
\hline
\end{tabular}


Стратегія антимікробної терапії будується, у першу чергу, з урахуванням полімікробного характеру інфекції. Стартова антибактеріальна терапія базується на емпіричному підході з урахуванням переважного впливу на грампозитивні коки. Препаратами вибору є інгібіторозахистні пеніциліни й цефалоспорини, трохи менш ефективні фторхінолони. У випадку наявності ознак ішемії й помірних проявів інфекції виникає необхідність застосування комбінації антибіотиків цефалоспоринового ряду або фторхінолонів із метронідазолом або кліндаміцином. При ознаках остеомієліту найкращі результати досягнуті при використанні лінкозамідів і високих доз цефалоспоринів або фторхінолонів.

Перехід на етіотропну антибактеріальну терапію грунтується на результатах динамічного мікробіологічного дослідження ран. При резистентній мікрофлорі застосовують антибіотики резерву: ванкоміцин, карбопенеми, сучасні фторхінолони, лінезолід.

\section{СПИСОК ЛІТЕРАТУРИ}

1. Антибіотикорезистентність і система інфекційного контролю в хірургії / В. В. Грубнік, А. В. Малиновський, В.В.Бойко, В. Ю. Грубнік // Хірургічна перспектива - 2012. - № 1. C. $16-17$.

2. Лупальцов В. И. Современные взгляды на патогенетические механизмы развития сепсиса / В. И. Лупальцов, Н. А. Клименко // Сучасні медичні технології. - 2009. - № 4. - С. 56-59.

3. Микробиологическое исследование раневого отделяемого у больных с критической ишемией нижних конечностей / А. А. Зорькин, Е. В. Дрожжин, А. А. Цай [и др.] // Клиническая микробиология и антимикробная химиотерапия. -2009. T.11, № 2. - С. 15-16.

4. Горобейко М. Б. Міжнародна угода з проблеми діабетичної стопи / Під ред. М. Б. Горобейко. - К., 2004. - 96 с.

5. Комплексное хирургическое лечение синдрома стопы диабетика / В. В. Бойко, Ю.В.Иванова, Ю.В.Авдосьев [и др.] // Хірургічна перспектива. - 2014. - № 1(8). - С. 3-10.

6. Полищук Е. И. Этиологическая структура и антибиотикорезистентность основных возбудителей инфекций стопы у больных сахарным диабетом / Е. И. Полищук, Е. В. Покас,
Висновоки. 1. Таким чином, аналіз вказує на необхідність комплексного лікування хворих із гнійно-запальними ураженнями тканин із використанням середників, які пригнічують життєдіяльність збудників гнійних процесів і стимулюють захисні механізми макроорганізму.

2. Результати дослідження чутливості мікроорганізмів при госпіталізації свідчать про високу стійкість мікрофлори до антибіотиків I-II поколінь групи пеніцилінів, цефалоспоринів. Проте встановлено, що антибіотиками резерву залишаються препарати групи карбапенемів, оксазолідінонів, глікопептидів, до яких спостерігається висока чутливість мікроорганізмів.

Перспективи подальших досліджень. Отримані результати про бактеріальний “пейзаж” ускладнених форм синдрому діабетичної стопи в подальшому дадуть змогу оптимізувати антибактеріальну терапію, яка б ефективно доповнювала хірургічні методи лікування даної патології.

Е. Г. Василенко // Клиническая микробиология и антимикробная химиотерапия. - 2009. - Т. 11, № 2. - С. 31-32.

7. Підвищення ефективності дії антибактеріальних препаратів при лікуванні стопи діабетика / С. Є. Подпрятов, С. Г. Гичка, О. В. Паршиков, В. В.Салата [та ін.] // Хірургічна перспектива - 2012. - № 1. - С. 30-31.

8. All-cause mortality after diabetes-related amputation in Barbados: a prospective case-control study / I. R. Hambleton, R. Jonnalagadda, C. R. Davis [et al.] // Diabetes Care. - 2009. Vol. 32, No. 2. - P. 306-307.

9. Epidemiology and prevalence of methicillinresistant Staphylococcus aureus and Staphylococcus epidermidis in patients with diabetic foot ulcers: focus on the differences between species isolated from individuals with ischemic vs. neuropathic foot ulcers / H. Galkowska, A. Podbielska, W. L. Olszewski [et al.] // Diabetes Res. Clin. Pract. - 2009. - Vol. 84, No 2. -P. 187193.

10. Heffner A. C. Etiology of illness in patients with severe sepsis admitted to the hospital from the emergency department / A. C. Heffner, J. M. Horton, M. R. Marchick // Clin. Infect. Dis. 2010. - Vol. 50, No. 6. - P. 814-820.

\section{REFERENCES}

1. Hrubnik, V.V., Malynovskyi, A.V., Boiko, V.V., \& Hrubnik, V.Yu. (2012). Antybiotykorezystentnist i systema infektsiinoho kontroliu v khirurhii [Antibiotic resistance and infection control system in surgery]. Khirurhichna perspektyvaSurgical Perspective, 1, 16-17 [in Ukrainian].

2. Lupaltsov, V.I., \& Klimenko, N.A. (2009). Sovremennye vzglyady na patogeneticheskie mekhanizmy razvitiya sepsisa [Modern views on the pathogenetic mechanisms of sepsis development]. Suchasni medychni tekhnolohii - Modern Medical Technologies, 4, 56-59 [in Russian].

3. Zorkin, A.A., Drozhzhin, E.V., \& Tsay, A.A. (2009). Mikrobiologicheskoe issledovanie ranevogo otdelyaemogo u

bolnykh s kriticheskoy ishemiey nizhnikh konechnostey [Microbiological investigation of wound detachable in patients with critical ischemia of lower extremities]. Klinicheskaya mikrobiologiya i antimikrobnaya khimioterapiya - Clinical Microbiology and Antimicrobial, Chemotherapy 11 (2), 15-16 [in Russian].

4. Horobeiko, M.B. (2004). Mizhnarodna uhoda z problemy diabetychnoi stopy [International agreement on the problem of diabetic foot]. Kyiv [in Ukrainian].

5. Boyko, V.V., Ivanova, Yu.V., \& Avdosev, Iu.V. (2014). Kompleksnoe khirurgicheskoe lechenie sindroma stopy diabetika [Complex surgical treatment of diabetic foot syndrome]. Khirurhichna perspektyva - Surgical Prospect, 1 (8), 3-10 [in Russian]. 
6. Polishchuk, E.I., Pokas, E.V., \& Vasilenko, E.G. (2009). Etiologicheskaya struktura i antibiotikorezistentnost osnovnykh vozbuditeley infektsiy stopy u bolnykh sakharnym diabetom [The etiological structure and antibiotic resistance of the main pathogens of foot infections in patients with diabetes mellitus]. Klinicheskaya mikrobiologiya i antimikrobnaya khimioterapiya Clinical Microbiology and Antimicrobial Chemotherapy, 11 (2), 31-32 [in Russian].

7. Podpriatov, S.Ye., Hychka, S.H., Parshykov, O.V., \& Salata, V.V. (2012). Pidvyshchennia efektyvnosti dii antybakterialnykh preparativ pry likuvanni stopy diabetyka [Increase the effectiveness of antibacterial drugs in the treatment of diabetic foot]. Khirurhichna perspektyva - Surgical Prospect, 1, 30-31 [in Ukrainian].
8. Hambleton, I.R., Jonnalagadda, R., \& Davis, C.R. (2009). Allcause mortality after diabetes-related amputation in Barbados: a prospective case-control study. Diabetes Care, 32 (2), 306-307. 9. Galkowska, H., Podbielska, A.W., Olszewski, L. (2009). Epidemiology and prevalence of methicillinresistant Staphylococcus aureus and Staphylococcus epidermidis in patients with diabetic foot ulcers: focus on the differences between species isolated from individuals with ischemic vs. neuropathic foot ulcers. Diabetes Res. Clin. Pract., 84 (2), 187-193.

10. Heffner, A.C., Horton, J.M., \& Marchick, M.R. (2010). Etiology of illness in patients with severe sepsis admitted to the hospital from the emergency department. Clin. Infect. Dis., 50 (6), 814-820.

Отримано 14.02.2018

\section{YA. DZYUBANOVSKY ${ }^{1}$ R. YA. ANTOSHCHUK}

I. Horbachevsky Ternopil State Medical University ${ }^{1}$, Volyn Regional Hospital of War Veterans ${ }^{2}$

\section{BACTERIAL "LANDSCAPE" OF PURULENT FOCUS AND PRINCIPLES OF ANTIBIOTIC THERAPY IN PATIENTS WITH DIABETIC FOOT SYNDROME}

The aim of the work: assessment of the bacterial spectrum and the effectiveness of the appointment of antibacterial therapy in patients with diabetic foot syndrome.

Materials and Methods. The results of the treatment of 269 patients (148 (55.01\%) men and 121 (44.09 \%) women) were analyzed. They were at inpatient treatment in the Surgical Department with Osteomyelitis Center on the basis of the Volyn Regional Hospital of War Veterans on the purulent-necrotic complications of SDS. All examined patients were pre-treated in surgical hospitals in the region regarding purulent-necrotic SDS processes, which was carried out empirical antibiotic therapy for up to 10 days. The neuropathic form of SDS was established in 84 (31.2 \%) patients, mixed - 148 (55.01\%), ischemic - 37 (13.7 \%). The prevalence of purulent necrotic process in patients with SDS, according to the classification of Wagner: I degree - 20 (7.4\%), II degree - 92 (34.2 \%), III degree - 70 (26\%), IV degree -65 (24.2\%), V degree - 22 (8.2\%). The complex of bacteriological studies consisted in the study of wound exudate with the identification of the microflora of purulent necrotic center and the evaluation of its sensitivity to antibiotics and cytological examination of smears-impressions from the wound surface. Identification of pathogens of the infectious process was carried out by cropping method on the appropriate nutrient medium, and sensitivity to antibiotics was determined by the disc diffusion method.

Results and Discussion. The microbial landscape of purulent-necrotic lesions in patients with diabetes mellitus is mainly polyvalent in $54.6 \%$ of cases, and monoculture in $45.4 \%$ of patients. The largest number of microbial associations sown from the primary purulent cell were aerobic associations - $54.6 \%$. Aerobic-anaerobic associations were sown in isolated cases, and sowing of anaerobic associations was not noted. The main representative of the mixed aerobic infection was Staphylococcus aureus. Often Staphylococcus aureus was sown along with the gram-positive sticks - Enterococcus faecalis, Corynebacterium xerosis and Staphilococcus epidermidis. The greatest clinical significance of the group of non-fermenting microorganisms in the aerobic association is Pseudomonas aeruginosa. The results of the study of the sensitivity of microorganisms during hospitalization indicate a high resistance of the microflora to antibiotics I-II generations of the penicillin group, cephalosporins. Antibiotics of the reserve are preparations of the group of carbapenems, oxazolidinones, glycopeptides.

Key words: diabetic foot syndrome; bacterial landscape; antibiotic susceptibility. 


\section{и. Я. ДЗЮБАНОВСКИЙ}

ГВУз “Тернопольский государственный медицинский университет имени И. Я. Горбачевского МЗ Украины”

Волынский областной госпиталь ветеранов войны ${ }^{2}$

\section{БАКТЕРИАЛЬНЫЙ “ПЕЙЗАЖ” ГНОЙНОГО ОЧАГА И ПРИНЦИПЫ АНТИБАКТЕРИАЛЬНОЙ ТЕРАПИИ У БОЛЬНЫХ С СИНДРОМОМ ДИАБЕТИЧЕСКОЙ СТОПЫ}

Цель работы: оценка бактериального спектра и эффективности назначения антибактериальной терапии у больных с синдромом диабетической стопы.

Материалы и методы. Проанализированы результаты лечения 269 больных (148 (55,01 \%) мужчин и 121 (44,09 \%) женщин), находившихся на стационарном лечении в хирургическом отделении с остеомиелитным центром на базе Волынского областного госпиталя ветеранов войны по поводу гнойно-некротических осложнений СДС. Все обследованные пациенты предварительно лечились в хирургических стационарах области по поводу гнойно-некротических процессов СДС, которым осуществлялась эмпирическая антибиотикотерапия продолжительностью до 10 дней. Нейропатическую форму СДС установлено в 84 (31,2 \%) пациентов, смешанную - 148 (55,01 \%), ишемическую - 37 (13,7 \%). Распространенность гнойно-некротического процесса у больных с СДС, согласно классификации Wagner: I степень 20 (7,4 \%), II степень - 92 (34,2 \%), III степень - 70 (26 \%), IV степень - 65 (24,2 \%), V степень - 22 (8,2 \%). Комплекс бактериологических исследований заключался в исследовании раневого экссудата с идентификацией микрофлоры гнойнонекротического очага и оценке ее чувствительности к антибиотикам и цитологическом исследовании мазков-отпечатков с раневой поверхности. Идентификация возбудителей инфекционного процесса осуществлялась методом посевов на соответствующие питательные среды, а чувствительность к антибиотикам определялась диско-диффузным методом. Результаты исследований и их обсуждение. Микробный пейзаж гнойно-некротических очагов у больных с СД носит преимущественно поливалентный характер 54,6 \% случаев, а монокультуру в 45,4 \% пациентов. Наибольшее количество микробных ассоциаций, что высевались из первичного гнойного очага, составили аэробные ассоциации - 54,6 \%. Аэробноанаэробные ассоциации высевались в единичных случаях, а посева анаэробных ассоциаций не отмечалось. Основным представителем смешанной аэробных инфекции был Staphylococcus aureus. Чаще всего Staphylococcus aureus высевался вместе с граммположительными палочками - Enterococcus faecalis, Corynebacterium xerosis и Staphilococcus epidermidis. Наибольшее клиническое значение из группы неферментирующих микроорганизмов в составе аэробных ассоциаций имеет Pseudomonas aeruginosa. Результаты исследования чувствительности микроорганизмов при поступлении свидетельствуют о высокой устойчивости микрофлоры к антибиотикам I-II поколений группы пенициллина, цефалоспоринов. Антибиотиками резерва остаются препараты группы карбапенемов, оксазолидиноны, гликопептидов.

Ключевые слова: синдром диабетической стопы; бактериальный пейзаж; антибиотикочувствительность. 